\title{
SODAT EK HOM MAG KEN
}

\author{
PROF. DR. J. A. LOMBARD
}

Dit gaan hier onmiddellik om die diepste en geheimnisvolste van alle vrae in die hele teologie: hoe dat ek God kan ken. Dit is die vraag na die teologiese hermeneutiek. Maar nou sou iedereen ook dadelik kon bemerk dat in ons denke en woordvorming ons geneig is om die woorde, en die gang van die "getuienis" aangaande HOM, subtiel te verander, naamlik ",hoe" „kan" ons God ken, in plaas van dáárdie woord dat ek Hom mag ken. Daarmee - in alle cenvoud - is ook alreeds die wese van die hermeneutiese probleem gestel: Wie is God en wat sê Hy? En wie is die mens en wat dink hy? Die eenvoudigste - en tegelyk mees beslissende! - voorbeeld sal dit illustreer: nêrens in die geskrifte van die Ou of Nuwe Testament word gevra of 'n lewende God wel „eksisteer” nie; maar: WIE IS HY! Nêrens word gespekuleer of daar moontlik in communicatio tussen God en mens - en dan tussen Gemeente en wêreld - kan plaasvind nie: maar die geskiedenis van Gods missio is eenvoudig daar en daarom ók die antwoord van die mens aan Hom en daarom ook die uitgaan van dieselfde mens met 'n boodskap tot die helc wêreld. Daarom sal dit nou vir ons ook gaan: die hermeneutiese vraag - eers in die algemeen wat ons daarvan gemaak het in Kerk en teologie en dan wil ons ook, in deemoed en tog onverskrokke, die enigste weg, soos ons dit van Hom leer, probeer aantoon.

die aanvaarding van sy professoraat wat op 7 September 1938, by die aanvaarding van sy professoraat, meteens standpunt ingeneem het in die midde van die hermeneutiese woelinge van dié tyd'). Met ' $n$ allesomkerende krag het die nuwe hermeneutiek na alle kante nuwe weë gebaan. Vra ons egter vandag waarom daar so weinig tereg gekom het van die wonderlike beloftes wat uit hierdie rede spreek en waarom tot op hierdie uur die verhouding tussen eksegese en dogmatiek so onvrugbaar bly en waarom daar in die algemeen nie beweging skyn te kom in die "Gereformeerde teologie" in Suid-Afrika nie, dan is een saak onmiskenbaar deursigtig: in Groenewald se rede word fris en pragtig oor die eksegetiese taak gespreek, maar hy laat dit glanshelder word dat die vraag na die verstaan heeltemal apart gehou word van die grammaties-historiese ondersoek²). Miskien moet

1. E. P. Groenewald Die Eksegese van die Nuwe Testament, Pretoria, 1938.

2. a.w., bl. 5. bv. ,.Op die wysgerige vraag van die verstaan kan ons hier nie ingaan nie." Vgl. verder ...simboliese meerwaarde", bl. 6; "deur sintese" kom tot "die diepe sin", bl. 7, ens. 
dit - met al die groot respek vir die eksegetiese teoloog! nog duideliker aangemerk word dat in daardie tyd die dogmatiese stellings sonder meer as klaar en afgehandelde gegewenhede aanvaar word ${ }^{3}$ ). Deurdat Groenewald so sterk daarop gelet het dat die eksegese nie by „filologiese" arbeid bly staan nie, nie tevrede is met die "historiese" konteks nie, maar wil deurdring tot "wat bedoel word", dat dit vra na die "teologiese eksegese”, behoort 'n deurbraak hier plaas te gevind het. Hy was die "algemene kerklikheid" vér vooruit. Maar de facto het van eksegetiese-dogmatiese bevrugting (en selfs 'n gesprek!) weinig tereg gekom; en ons sit na meer as dertig jaar net waar ons tevore was wat die basiese vrae betref insake die verstaan, die struktuur, die Woord van God en die woord van die mens, en veral die diepe en geheimnisvolle vraag wat is die boodskap van die Heilige Skrif; hoe leer ek God ken daarin; hoe ken en hoe durf ek Gods gedagtes dink en Sy woord uitlê! Die vraag ,,vom Verstehen" kan langer by ons nie meer geïgnoreer word nie; en die tyd het lank reeds aangebreek dat eksegese en dogmatiek saaklik in gesprek moet kom.

Die opdrag is aan my gegee, om iets van die ontwikkelingsgang in die hermeneutiek mee te deel. Ek het gekies om die enkele vraag van „Hom te ken" naderby te besien. Om die volle gewig van hierdie „ken van God" enigsins te verduidelik, sal die basiese riglyne eers aangestip word: as minimum voorvereiste is nodig om in oënskou te neem die vraag, die hermeneutiese gang, die nuwere teologiegeskiedenis en die huidige situasie, om dan baie kort 'n eie bydrae te probeer lewer omtrent die ken van God.

1.

Die vraag is: hoe kan ek God ken?

Die antwoord van dertig jaar gelede (hier by ons!) kan net nie meer gegee word nie, naamlik dat die skrywers en lesers van die Skrif "weet van die inwerking van Gods werklikheid in die wêreld", of dat ", die openbaring van God" ingelê is ,in die geskrewe Woord". Daardie ongestoorde en ongeskokte wêreld waar ons "God", sy Woord", sy „openbaring" heeltemal toeganklik voor ons het, daardie rustige habitas en securitas teologie bestaan nie meer nie').

3. Vgl. bv. bl. 15 ..Daarom is dit die taak van die eksegese om deur te dring deur die vorm van die geskrewe Woord tot die goddelike inhoud." Sodra die eksegeet.enige eksegeet (grammatieshistories. psigologies, fenomenologies- of hoe dan ook ingestel) sê: hierdie teks is "goddelik", of ..Gods Woord", of .,dit is Gods Openbaring", dan is dit 'n dogmatiese stelling, en is die dogmatiese vrae nie meer te ontwrk nie.

4. Behalwe moontlik in sekere „eilande" in Australië (of Holland of Amerika?) waar 'n mens sonder blik of bloos "God" en die Heilige Skrif kan identifiseer. 
'n Ontleding en geskiedenis van die woord hermenia ${ }^{5}$ ) is nie ons taak nie;; maar sowel leksikografiese as die feitelike historiese gegewens kan die student in 'n ry van handboeke ${ }^{i}$ ) nalees. Interessant is die vasstelling dat met Frederik Torm se werk (oorspronklik in Deens opgestel: Nytestamentlig Hermeneutik) die einde van die „tradisionele epog” aanbreek. Wat begin het as die probleme insake vertaling, uitleg, interpretasie, verklaring, word oornag die vraag van verstaan! Meteens verskyn daar 'n lig wat sigbaar maak dat ons nie met "dinge" te doen het nie, nie natuurlike gegewens voor ons het nie, dat ook en veral die taal nie 'n natuurlike fenomeen is nie, maar geskiedenis; en nou gaan hoe langer hoe skerpsinniger die aandag konsentreer om "geschichtliches Verstehen". Die aangrypende feit sal altyd bly dat in hierdie oorgang in die geskiedenis van die geesteswetenskappe die teologiese hermeneutiek leiding gegee het en verandering bewerk het ook by ander wetenskappe, soos die folosofie. Nie van die algemene ,verstaanswêreld" het dit gekom tot die „Bybelse verstaan" nie, maar inteendeel die insig dat verstaan geskied in 'n konkrete situasie, met 'n bepaalde „Gegenüber", het die ander wetenskappe geleer dat ook dáár die ware insigte en „verstand" nie anders plaasvind nie.

Maar skerper en meer kernagtig is die vraag: "God ken?" Dit is vandag 'n stuk dogmengeskiedenis, maar die gloed van die debat word eers sigbaar as 'n mens weer nalees wat destyds gebeur het - so byvoorbeeld die briefwisseling tussen Adolf von Harnack en Karl Barth. Terwyl Von Harnack volhou dat die teoloog se taak is „om intellektueel in besit of beheer te

In hierdie en volgende kantaantekeninge wil ek dit duidelik stel dat nagestreef word om die allerminste minimum verwysings te doen dat die eerste lesing van hierdie artikel selfs sonder verwysings gelees kan word - maar dat hierdie ,eiserne Ration" dan tog respekteer moet word en wie saampraat en saamdink dit moet bestudeer!

Vir die ontleding en geskiedenis van ,hermeneia" sien o.m.: Kittel, Th.W., II; PRE, VII, 1899; RGG, 3 ed., III, 1959. 'n Groot literatuur verder by James M. Rohinson and John B. Cobb, Jr. The New Hermeneutic, vol. II, New York, 1964.

i. 'n Minimum sou hier wees: J. Ch.K. von Hoffmann, Biblische Hermeneutik. 1880; J. Wach, Das Verstehen, drie dele. I, 1926; II, 1929; III. 1933. E. Fascher, Vom Verstehen des Neuen Testament, 1930; Ernst von Dobschütz, Vom Auslegen des Neuen Testaments. 1927; F. W. Grosheide, Hermeneutiek. 1929; Fr. Torm, Hermeneutik des Neuen Testaments, 1930; S. Grijdanus, Schriftbeginselen ter Schriftverklaring. 1946; Ernst Fuchs, Hermeneutik, 1954.

Wat tussen hierdie hoofwerke verskyn is juis hermeneutiese arbeid in gespesialiseerde vorm of in ander verband, wat juis die stimulus was vir nuwe hermeneutiese ondersoeke, soos hv. „Der Römerbrief”, of die K.D. van Karl Barth. 
kom van sy objek", word Barth nie moeg om te herhaal dat hierdie objek was eers Subjek en die mens ken dit slegs as dit weer Subjek is; met ander woorde God is nie 'n fenomeen nie, tot beskikking van wetenskaplike navorsing, soos dit is met die fenomena van hierdie wêreld. Om te weet (gnonai) gryp wyd oor alle intellektuele „Inanspruchnahme hinaus”! Tot die lewende God het ons geen toegang nie. Of soos Jüngel dit vandag sou sê: „Gottes sein ist im Werden"'), om daarmee te verduidelik dat "die Lebendigkeit Gottes zu denken" kan ons slegs wanneer ons bevry is van rampspoedige "metafysiese geobjektiveerdheid" van God en begin verstaan dat Godself geskied dat in Hom (lank vóór ons van geskiedenis kan spreek) ewiglik Trinitaries ,geskiedenis” is. „Das Sein Gottes ist das hermeneutische Problem der Theologie. Genauer: dass das Sein Gottes gehat, ist das hermeneutische Problem schlechthin. Denn nur weil das Sein Gottes geht, kommt es zu Begegnung zwischen Gott und Mensch. Und eben in dieser sich der Bewegung des Seins Gottes verdankenden Begegnung swischen Gott und Mensch ist das hermeneutische Problem grundgelegt"').

Hier is op sy mees pregnante die hemeneutiese probleem gestel: hoe ken ek God? Nie anders as in sy geskiedenis in Homself nie, wat die grond en rede is van sy geskiedenis tot ons. En laat ons 'n oomblik die hele saak wat hier gestel word vooruitloop, dan is daar een woord en een Naam waarin hierdie geskiedenis gebeur: Jesus Christus!

Hiermee het ons ook klaar verduidelik waarom die hermeneutiek, en wel in besonder die hermeneutiese vraag na Godself, die kernvraag is van alle teologie, en dat dit in alle rigtings die karakter bepaal van alle teologiese ondersoek.

In die oorgang vanaf die „ou" hermeneutiek tot die nuwe het ons beweeg van die statiese, die bloot objektief-gegewene, selfs die eenvoudige samevatting van "language, historic setting, stylistic explanation", en siedaar die saak is verklaar, terwyl dié saak nog nie eers in sig gekom het nie! Minstens dit het ons vandag geleer dat selfs denke meer is as abstrakte refleksie: dis die aksie en reaksie van die hele mens in sy hele konkrete situasie, „Verstand" is veel meer as die Platoniese gedagte van „verligting"; veel anders as die Kantiaanse apriori's 'n „verneem” (en daarom ook 'n ,Selbstverständnis") sonder dat iets geskied;

'. Gedurende 1923; nou opgeneem in Karl Bartl. Theologische Fragen und Antworten: Gesammelte Vorträge. III. E.V. 1957.

?. Eberhard Jüngel. Gattes sein ist im Werden. Tübingen, 1965. Een van die beste en hoopvolste boeke van ons tyd!

9. a.w., bl. 10 . 
en gebeur ook nog op 'n gans ander vlak as die blote ,geschichtliche Vernuft" (vanaf Fichte tot Hegel) waar dit gaan om die "Refleksionstruktur des Denkens". Daarin het Pannenberg reg as hy die „eschatologiese Struktur der Vernunft” ontwikkel teenoor die starheid van die „Erkentenisvermoë" of selfs „ontwikkelingsgeskiedenis". Teenoor „die Vernunft" wat net van die "sigbare" geleef het, kom nou die „eschatologiese" ${ }^{10}$ ).

Ook dit alleen is nie genoeg nie, omdat hy, netsoos Moltman, 'n eschatologiese ruimte laat wat leeg is!

Maar dit is deel van die beweging, die egte theologia viatorum"). So is ook Ernst Fuchs in erns aan te hoor as hy die dringende erns van die hermeneutiese vraag aan die Amerikaners so stel: „we really do need to think about how one can speak of God and his works" "1"). Maar as die antropologiese „Vorverständnis" onmiddellik volg, word alles ook hier weer inhoudloos, naamlik ,"attempts to speak of God, but by means of man's understanding of himself as God's work" ${ }^{13}$ ).

In die verstaan van die lewende God styg ons in 'n bewegende trein: daar het reeds iets gebeur, daar gebeur nou iets, dit wys heen na 'n weg wat voor ons oopgaan. Ja, meer nog: die hele veld is in beslag geneem; die werklikheid waar dit om gaan, vul reeds alles. „In einer rechten biblischen Hermeneutik treten wir nicht, ausgerüstet mit einem allgemeinen Verstehensvermögen, zur Eroberung eines Segments des Seins an, sondern wir folgen der konkreten Bewegung des Verstehens, das da schon im Gange ist vom Inhalt der Botschaft aus" ${ }^{14}$ ).

Ons is hiermee by die grense van die wesenlike verskil tussen die „ou" wyse van verstaan en die geheel nuwe insig" van die waarheid as 'n totale geskiedenis, 'n totale beweging. En daarby, die wesensverskil tussen verstaan in die algemeen en die vraag na God: in alle blote „wetenskaplike" verstaan is die ontmoeting (hoor, aanskou . . .) en die uitleg (uiteensetting, ,verklaring") genoeg; daar is geen moet dat die persoon betrek word nie, daar hoef geen "Anwendung" te wees nie. In die ken van

i". Wolfhart Pannenberg, Grundfragen systematischer Theologie, Göttingen, 1967. bl. 250.

11. Vgl. James W. Leitch. A Theology of Transition. London 1952. Dit is die teologie van H. R. Mackintosh soos weergegee in Leitch se doktorale proefskrif - nog'n goeie werk wat gelees moet word in die groot samehang van hierdie onderwerp, al kan ons weinig nou daarna verwys.

12. Robinson and Cobb, a.w., bl. 116. Art. van Fuchs: The New Testament and the Hermeneutical problem, bl. 111-145.

1.i. a.w.. bl. 117.

14. K. H. Miskotte, Zur biblishen Hermeneutik, E.V., (Th. St., Heft 55), 1959 , bl. 16. 
HOM is onsydige, neutrale, louter ongeinteresseerde kennis onmoontlik. Is dit werklik God, die Here, van wie ons hier praat, dan gaan dit om Gods alles en die alles van die mens.

2.

Die Hermeneutiese Gang. In hierdie en die volgende paragraaf gaan dit heel eenvoudig om die konteks van die hermeneutiese vrae binne die teologiegeskiedenis. Dit is dus toelaatbaar (en vir hierdie geleentheid selfs gerade) om nou werklik slegs 'n paar grensbakens op te rig. Maar dit is wel noodsaaklik om die perspektiewe baie helder te hê: vanwaar ons kom en waarheen ons op weg is.

Dit is vandag ' $n$ algemene aanvaarde feit dat met Schleiermacher (1799) 'n nuwe periode in die teologiegeskiedenis begin, 'n onmiskenbare caesura, wat diep ingesny het ${ }^{15}$ ). Dit is teen die agtergrond van daardie hele $19 \mathrm{e}$ eeu wat die Evangeliese Teologie van die 20e eeu gearbei het. Stemme word alreeds gehoor, en dit is my oortuiging dat ook hierdie erkentenis spoedig algemeen sal deurwerk, dat met Karl Barth minstens 'n ganse periode beëindig is ${ }^{16}$ ).

Laat ons in algemene omlyning sien wat gebeur in hierdie tyd. Schleiermacher tree as verdediger van die Christelike godsdiens op, op so 'n wyse dat hy dit ,apologeties" probeer onaantasbaar stel in die diepste ,innerlikheid" tussen God en die mens. Daarom sny hy die hermeneutiese probleem wyd aan en vra die verstaan in sy wydste en kultureel verfyndste betekenis. Maar alreeds Schleiermacher skei hermeneutiek van linguistiek en geskiedwetenskap. Hy begin vra na die betekenis in sy eiesoortige karakter. Vanhier volg die weg van toespitsing en al nouer wordende spesialisasie. Algaande verdwyn hermeneutiek as selfstandige dissipline en word behandel in onderdele byvoorbeeld selfstandig vir Ou of Nuwe Testament. Terwyl daar tussen 1720 en 1820 'n stroom hermeneutieke verskyn, ontstaan daar gaandeweg 'n vakuum, sodat Von Dobschütz in 1927 opmerk dat na J. Ch. K. van Hofmann se „Biblische Hermeneutik" daar tot op sy tyd niks van betekenis verskyn het nie.

\footnotetext{
1.. K. Barth Die protestantische Theologie im 19 Jahrhundert, E.V., 1946, bl. 379 .

11. Daarom ook is Bulmann, cum suis, se onderneming - die basies antropologiese uitgang punt - 'n heillose onderneming: dit is überholt.

1i. E. von Dobschütz a.w., 1927, bl. 6. Vgl. ook Groenewald. a.w., bl. 4 , voetn. 5). Let daarop dat terwyl in die PRE, 3 ed., VII, nog veel oor hermeneutik verskyn dit in die RGG, 2 ed. heeltemal verdwyn het en eers weer in die 3 ed. verskyn!
} 
Terwyl dit so is dat die "scholarly hermeneutic" met Schleiermacher begin, was dit in werklikheid die Reformasie as sodanig wat verantwoordelik was vir die wetenskap van die hermeneutica ${ }^{18}$ ).

Die sogenaamde „klassieke ortodokse” opvatting dat „die Skrif" sonder meer gelyk is aan Gods Woord, is sekerlik nie Reformatories of „Gereformeerd" nie, maar 'n latere wanstaltige poging om die "Skrifgesag" te beskerm en vas te lê. Die hermeneutiese reël wat van die Reformatoriese "vadere" ontvang is, was eerder scriptura scripturae interpres. Tussen Woord en Skrif was daar altyd 'n ander ,instansie" en dit nie die ,Zwischeninstanz" van biskop of ook Kerk nie, maar wel ,das Evangelium" - (vgl. die Heidelbergse Kategismus, vraag 19) ${ }^{19}$ ).

Miskotte se bekende radio-voorlesings van Oktober-November 1957 neem prakties Luther se beroemde woorde, uitgespreek twee dae voor sy dood, as teks ${ }^{20}$ ) en dan gryp hy veral die slotreëls vas: hanc tu ne divinam Aeneida tenta, sed vestigia pronus adora. Wir sind pettler. Hoc est verum. (Vertaal: Moenie probeer om die goddelike Aeneis te onderneem nie, maar buig jou diep aanbiddend voor sy voetspore. Ons is bedelaars. Dit is waar). Soos 'n refrein gaan die ondersoek na hierdie vestigia nou deur Miskotte se voorlesings. Dit dan is die ware erfenis wat van Luther en "die vadere" kom: wat is die "Grundstrukturen", die "geistliche Idiom der Schrift", die „eigentümliche Sprache”, die „Lineamenten der Schrift"21). Ek dink dat die woorde van Luther - deur Barth vooropgestel in sy „Die Lehre vom Wort Gottes", K.D., 1, 2-profeties is nie net vir Luther nie, maar vir Calvyn en al die groot Reformatore: „Jesus Christus, Heri, et hodie, et in secula . . . Ja, so heisst der Man, und so heist kein ander Man, und sol auch keiner so heissen ... Christus unser lieber Gott und Bischoff unser Seelen, die er durch sein theurer Blut erkaufft hat, erhalte seine kleine Herde bey seinem heiligen Wort, das sie zuneme und wachse in der gnade, erkentnis und glauben an jn ..."

18. Vgl. Wilhelm Dilthey „Die Entstehung der Hermeneutik”, aangeh. by Robinson and Cobb, a.w., bl. 9. Naas die Latynse uitdrukking ars interpretandi, kom nou die Grieks-georiënteerde woord en begrip

19. Vgl. Miskotte, a.w., bl. 12, 13, wat ook nie net deur Gerhard Ebeling gesê word nie, maar juis hulle wat uitdruklik van GereformeerdReformatoriese sy kom, Roger Mehl, Hermann Diem, Otto Weber.

20. Sien Miskotte, a.w., bl. 6.

21. a.w., bl. 28 e.v. 
Dit is seker: vir die Reformatoriese deurbraak was één ding van belang, die ken en verstaan van daardie EEN NAAM! Dit was hulle "Skrifprinsiepe" ${ }^{22}$ ). Dit is waar dat Melanchthon en Zwingli uitgeblink het in "noukeurigheid van woordverklaring", maar dan tog binne die groot raamwerk van Luther en Calvyn waar alles gedraai het om die boodskap en die verkondiging daarvan.

Die grootste vervlakking ná die Hervorming word gekenmerk deur die gebruik van die Skrif vir „tekste" wat as „,bewysplekke” moet dien vir dogmatiese loci. Daarmee tree 'n dogmatiese en konfessionele verkalking in wat tot vandag toe by sekere „konserwatismes" nog nie verbreek is nie - maar wel as struikelblokke dien om die Skrif nou werklik as Gods Woord te hoor!

Rondom die eerste jare van die $19 \mathrm{e}$ eeu gaan daar van die Kerk 'n wonderlike missionêre krag uit. Dit word sigbaar in die stigting van sendinggenootskappe, in die publikasies en veral in die oorvloedige beklemtoning van "die Koninkryk van God" of van Jesus. Ek hoef maar net te verwys na die „Missions Magazine", die oudste sendingtydskrif wat in 1816 begin; na die stigtings-motiewe vir sendinggenootskappe (die eerste sendinggenootskap in Duitsland, te Elberfeld, 1799) „ter wille van die koms van die Ryk"; en die talle „Nachrichten” wat almal min of meer so lees: „von des Ausbreitung des Reiches Jesu überhaupt"; ,Wichtige Nachricht aus dem Reich Gottes e.s.m. ${ }^{23}$ ). Warneck som in een sin die gees in Kerk en teologie goed op ... „,ein protestantisches Missionszeitalter ist ernst mit diesem Jahrhundert angebrochen" (dit sê hy in 1900, Alg. Miss. Zeit., bl. 33! Maar te gou verstar die ,goeie piëtistiese” dryfkrag en voor die jaar 1840 word alles verkerklik. Die klanke daarvan word in elke rigting gehoor; en dit heet: „Mission und Kirche”, (boek van A. Petri, Hannover, 1841); „Drei Bücher von der Kirche", (Wilhelm Löhe, 1844); en so het dit voortgegaan: vier en tot „agt boeke van die Kerk". Die sending se tyd „der

22. Begryplikerwyse is dit nie hier die plek om in detail na die Reformatore te verwys nie; oorbekend is tog dat dit vir Luther om Christus gaan (Christumtreiben), en alhoewel Calvyn se, Institutio" nie vanuit 'n bepaalde sentrum geskrywe is nie. ken hy net een "de jure" grond vir die krag en gesag van die Skrif, ,die eie lewende stem, of woorde van Godself": vivae ipsae Dei voces. (Inst. I. 7,1 ).

23. Hier gaan sendingwetenskaolik 'n hele wêreld oop, wat ons. hoe spannend ookal, hier nie verder kan volg nie. Ek verwys alleenlik na die werke van: G. Schrenk. Gottesreich und Bund, 1923; E. Schick, Verboten und Bahnbrecher, 1942; en die baie sendingtydskrifte. 
Unmittelbarkeit und Unschuld"'24) was verby. Soos die sending, so word die teologie 'n diens, nie meer aan die Koninkryk nie, maar aan die kerklike institusies.

Die teologie word binne die volgende jare ongewapend, staties en in 'n steriele toestand betrap deur die natuurweten. skaplike ontdekkings, met name Darwin se ewolusie-hipotese. Teen die tyd wat Warneck die oes van sy arbeid in 'n paar hoofwerke versamel-dus binne die volgende kwarteeu, circa 1875het alles te staan gekom onder die ban van 'n algemene proses van ontwikkeling! Die Koninkryk van God en van Christus is los van die Evangeliese middelpunt en staan in die teken van natuurlike vooruitgang. Was dit droewig duidelik hoe 'n statiese en fundamentalistiese Skrifgebruik 'n leegte op die Vasteland veroorsaak het - en nie die minste in "Gereformeerde" kringe nie! - dan het dit in Brittanje eksemplaries duidelik geword hoe seer die Evangeliese teologie verdwyn het, ten gunste van 'n komiese vermenging van 'n natuurwetenskaplike filosofiese ideologiese ",belief in progress" waarvan John Baillie een van die beste voorbeelde lewer. Konsekwent, in byna al sy werke is die idee van "progress" en die ,scientific method" met die gedagte van 'n voorwaartse en opwaartse stuwing:" $)$. Georg Heinrici se samevatting in 1899, met 'n supplement in 1913 tref die kern van die saak naaldskerp: „Die Wissenschaft der Gegenwart sammelt und bucht mit besonderem Interesse Tatsachen, sie freut sich an statistischen Erhebungen und bemüht sich um Verwertung der naturwissenschaftlichen Erkenntnisse auch für die Weltanschauung ... Der Grunton, der weite Kreise der Forscher bestimmt, ist von den Empiristen Englands und Amerikas angegeben ... " ${ }^{26}$ ).

Dit is duidelik waarom in die krisis-ure van die twintigste eeu - teen 1910 byvoorbeeld toe die internasionale spannings oplaai - daar vir meer as 'n geslag geen plek meer was vir enige Bybelse Hermeneutiek nie.

"'. In die steeds bruikbare boek yan J. C. Hoekendijk. Kerk en Volk. 1948 , oor die tydperk $1836-1874$, veel goeie materiaal en ryke bibliografie.

$\because$ John Baillie, Belief in Progress. 1951; Natural science and the Spiritual Life, 1951: maar sien ook sy boek ,.Our Knowledge of God" waarin ..neoorthodox and liberal theories of religious knowledge' gesif beoordeel word. Hoe ver die idee van "development and scientific method" gaan, word vir ons ook ondersoek en grondig weergegee by T. F. Torrance; Vgl. sy Theology in Reconstruction. bl. 62 e.v. Uiters belangrike gegewens en vergesigte by Walter Marshall Horton, Chrisiian Theology. 1956. Horton bring skerp in fokus die botsing tussen "American activists" and "Continental quietists" - hiervoor hf. VIII, The Christian Hope. bl. 244.274.

$\because$. PRE. 3 ed., XXIII, bl. 642. Vgl.in Engelse vertaling by Rohinson and Cobb, a.w., bl. 17 e.v. 
Maar ook op die Vasteland en by name in Duitsland het die teologie net geen plek meer vir die hermeneutiek gehad nie. In die rustige droomwêreld van 'n „etiese-religieuse gemeenskap" deur Jesus gestig (Ritchl!) en deur die Kerk verwesenlik op 'n immanente wyse in hierdie wêreld kan geen "heilige onrus" ontwaak nie. Die eschatologiese klop aan die deur was al luid"“) van die kant van die Nuwe Testamentiese ondersoek, toe die idealistiese lewensbeskouing almal nog droomverlore laat uitsien na die "humanisering en die etisering" van die mensdom sonder "eschatologiese katastrofes", sonder 'n God wat werklik in ons tyd en ruimte kan deurbreek. Een na die ander het hulle gekom: Albert Schweitzer, wie se "Leben - Jesu - Forchung”, die ou „Jesus-beelde" ter syde doen, en meteens staan dié Jesus voor ons van die eschatologiese spanning. Trompop volg die verkondiging van die Koninkryk (Weiss), en daarna Bousset, 'n ,zeitbedingte", 'n ,fenomenologiese" Jesus-beeld, maar Apokalipties, nie rasioneel-eties nie!

En tog - nog was die ou 19e eeuse wêreld daar! Adolf von Harnack met "Das Wesen des Christentums” (1905 en weer 1910) waar dit alles steeds gaan om vorm en inhoud, die uiterlike vorm van tydsbepaaldheid uit die „Umwelt" wat daargelaat kan word, en die kern wat die wesenlike is, „God en die siel, die siel en God"28). Dit bly dus rasioneel-eties; van belang is die indiwiduele mense-siel, die Vaderskap van God, die humaniteit van die mens. Geen ,geschichtliche”, geen „eschatologiese”, geen „kosmologiese" probleme hier nie. So was dit tot kort voor die "sondvloed" wat voor die deur van die jare 1910 gewag het!

So dan kom ons aan die einde van 'n periode wat hermeneuties in volkome leegheid en eensaamheid eindig. Die voortelling van 'n „völlige Teilnahmlosigkeit” het „etwa um 1910, in der protestantischen Theologie schon beinahe kanonisch" geword $^{2 y}$ ).

Die lewende God het geen ruimte gehad om iets te sê nie, want die Kerk en die teologie, die ,gesiviliseerde" mens van die eeu het alles goed onder beheer gehad, byna so netjies en sekuur soos die groot inkwisiteur van Dostoewski.

:7. Johannes Weiss. Die Predigt Jesu vom Reiche Gottes, 1892.

2x. Herman Ridjerbos, De Komst van hel Koninkrijk, 1950, een van die baie goeie boeke van ons tyd. Vir hierdie deel van ons studie is sy Inleiding van groot en blywende waarde.

20. Karl Barth, K.D.. I. 2. bl. 519. 
Die Groot Deurbreek staan geheel enig en alleen in nuwere teologie.

In die leegte wat daar ontstaan het, word op eenmaal 'n profetiese stem gehoor - en dit nie uit die sogenaamde konserwatiewe kringe nie, ook nie vanaf diegene wat nou juis Skrifstudie of sending-arbeid vooropstel nie. Die deurbreek kom vanaf iemand wat juis teenoor "liberale" agtergronde moes studeer, wat daar net een ding kon leer: respek vir die geskiedenis. Maar die krag en majesteit van die stem wat meteens in die teologiese leegtes gehoor word, is juis nie dié van teologies-wetenskaplik oorredingskrag nie, en ook nie dié van kerklik outoritatiewe gesag nie, maar van 'n heel eenvoudige „Pfarrer" wat een lentemôre 'n tafel onder 'n kersieboom sit, daarop lê 'n geopende Bybel en terwyl hy lees hoor hy één ding en net hierdie één ding: God is God.

Dit is die deurbraak en die vernuwing waaragter ons in die teologiegeskiedenis nie meer kan teruggaan nie.

Wat is hier die kern van die saak? Wat het basies hier gebeur vir die hermeneutiese ondersoek?

Ek vat net saam, omdat die geheel selfs van die buitelyne te omvangryk is vir hierdie klein studie. Also, wat onder die mees wesenlike moet hier gehoor word?

Dit is eerste en dit is laaste dat met God ons nie in die algemeen begin nie; daar is geen algemena godheid nie: God is hierdie één God en Here, of ons is alleen!

Dáárom begin Karl Barth in die hoor en verstaan van Wie God is radikaal vanaf die oord waar die profeties-apostoliese verkondiging hulle bevind. En wat is dit hier wat al die klein, nietige, relatiewe vooropstellings na niks laat lyk nie: „die krag om te begryp (katala besthai), zuerkennen die die Erkeinntnis übersteigende Liebe des Christus" (Ef. 3:18); wat „die skatte van wysheid en erkentenis” is, „ein vollmächtiges Aufnehmen und Verstehen der von ihnen (d.i. die apostels) bezeugten Offenbarung" (vgl. K.D. I, 2, bl. 779).

Aldus het ons nou met menslike kennis te doen wat nie eiemagtig is nie, maar rus in Wie God is en daarin dat die lewende God oor die grense kom en die mag van Sy Woord waar maak.

Nou gaan Barth terug na die Reformatore, soos hy eers teruggegaan het na die getuienis van Godself. By Calvyn kry hy "das Königtum Jesu Christi" wat volgens Calvyn se kategismus so heet: quod eius beneficio ... vindicati in libertatem conscientiarum, spiritualiousque eius divitiis instructi, potentia quoque armamur (Cat. Genev. 1545), waar conscientia (suneidésis 
- Gr. letterlik beteken: „Mit Wissen um das, was Gott weiss”30).

Ons is dus geheel-en-al in die diepte waar ons nie met 'n blote "objek" te doen het nie, maar "Gegenstand" (ook dikwels later "Gegenüber) wat Subjek is en bly; ons het te doen met die Woord as Gods eie vryheid wat aan ons geskied as „Ereignis". Hier is loutere geskenk en nie ons eie besitting of ons roem nie.

Met Calvyn en op hierdie weg soek Barth na die communio van andere wat geworstel het om te kom tot die gronde van die saak. ' $n$ Teken van hierdie soeke is die nuwe uitgawe van die ou werk van Heinrich Heppe $^{31}$ ) wat 'n compendium is van oudGereformeerde geskrifte waaronder die werke van Amandus Polanus $^{32}$ ) en Johannes Wollebius ${ }^{33}$ ) in die eerste ry van belangrikheid verskyn.

Met Wollebius sê Barth staan die frequens oratio ,an der Spitze”, want hoe moet ons God ken deur "Sprachenstudium, Quellenforschung usf," „weil wir Gottes nicht mächtig sind" ${ }^{34}$ ). Wat ons van onsself uit kan ken, is nie God nie, tensy Hyself ons weg fakties deurbreek nie. En wie is ons wat onsself nie eers ken nie. Also: „Nur in dieser Totalität sind wir ja wirklich wir selbst: fehlte auch nur eine Sekunde meines zeitlichen Daseins und fehlte auch nur ein Haar auf meinem Haupt, so wäre ich ja nicht ich, nicht Mensch, nich dieser Mensch. In dieser Totalität bin ich gemeint und getroffen vom Worte Gottes oder ich bin es gar nicht” ${ }^{33}$ ). Miskotte het reg as hy saamvat: „Der Glaube beruht .. . ungeschützt auf dem Selbstzeugnis Gottes"; en 'n bietjie verder aan: „Hier, wie im Grunde überall, ist die Kirchliche Dogmatik der Versuch - eigentlich der erste konsequente Versuch - eine konzentrierte Hermeneutik nach allen seiten durchzuführen"36).

Dit is die saak waarom alles gaan: Karl Barth het die teologie teruggeroep tot hermeneutiese rekenskap, soos dit sedert die Hervorming nie gebeur het nie. Maar hy het verder gegaan: wat hinkend en gebroke by Luther en Calvyn voorkom, klink deur sy hele dogmatiek soos 'n hooglied dat die geloof ook as ons dit verstaan as „unser eigenes Ergreifen . . . primär und wesenlich der Glaube an Jesus Christus ist. Auch er und also auch jene besonderen Ereignisse des Glaubens . . . nur von Jesus Christus her, wirklich sind ${ }^{3 i}$ ).

\footnotetext{
:a". a.w., bl. $\mathbf{7 8 0}$.

31. Reformierte Dogmatik, 1935, met ter inleiding, „Zum Geleit”, 'n woord van Karl Barth.

:2. Syntagma theologiae Christianae, 1624.

:33. Christianae theologiae compendium, 1626.

3i. K. Barth, a.w., bl. 782 .

35. a.w. bl. 791.

6. Miskotte, a.w., bl. 26.

3i. Barth, a.w., bl. 793.
} 
In die gemeenskap van die „vadere” hoor en leer ons nuut verstaan wat dit beteken: scriptura scripturae interpres en scriptura sui ipsius interpres. Polanus kom opnuut aan die woord: interpretatio sacrae Scripturae est explicatio veri sensus et ussu illius . . . ad gloriam Dei (Synt. Theol. chr. 1609, bl. 635) ${ }^{38}$ ).

Hoe in besonderhede uitgewerk word die explicatio, meditatio, applicatio, is so uiters nuttig, maar kan maklik nagelees word $^{39}$ ). Hier kom al ons menslike arbeid tot sy reg, nie net die literêr - historiese sy nie, maar ook die „bestimmte Erkenntnistheorie, Logik und Ethik"; ja waarom nie enige en alle ,filosofie" in diens stel aan sy woord waar dit pas nie, maar nooit as selfstandige instansie nie, nooit op die wyse dat die „Hermeneutik” wat die „Nahme Jesus Christus” uitlê „,ein spezialfall der allgemeinen Hermeneutik" word nie. Dit is met hande te gryp dat niemand, ook nie die grootste teoloë sonder enige filosofiese voorspellings was nie, Luther was bv. meer neo-platonies, Calvyn meer oud-platonies; by die Tübinger-Schule was dit Hegel en agter die „formgeschichtliche Exegese" staan veel van Hüsserl se fenomenologie - om te begin, kom elkeen met sy „vooropstellings", maar: „Wir müssen uns klar sein darüber, dass jeder von uns mitgebrachte Denkschematimus grundsätzlich ein anderer ist als der des von uns zu erklärenden Schriftwortes, so gewiss des Gegenstand Gottes Offenbarung in Jesus Christus, so gewiss es das durch den Heiligen Geist geschaffene Zeugnis von dieser Offenbarung ist . .." $\left.{ }^{\prime \prime}\right)$. Dit is verbysterend dat na 'n geslag skynbaar soveel wat ons reeds in die dertiger jare geleer het, vergeet word, sodat die onsinnige kan geskied dat iemand soos Runia by tye Barth en Bultmann in een bootjie probeer inpas (!) en dat - wat nog heilloser is, van die BultmannSchüler die reiniging van die teologiese huis totaal vergeet het, die waarskuwing dat iedereen wat meen dat hy 'n ,adăquates Instrument" het teenoor die lewende God, nicht mehr als Mensch . . . sondern als ein zweiter Gott" teenoor die Woord staan, en hierdie ,god" kan „nicht mehr der wahre Gott sein" want teenoor die Heilige is ons nie inter pares nie!"1). Enige absoluut-gesette prinsipes teenoor Hom, is nie kennis nie, maar die daad van ongeloof.

Wat dan in die geskiedenis van die menslike denkwyse het die krag om ons toe te rus met 'n potentia oboedientalis? Dit kan onder geen menslike denkreël gedefinieeer word nie. Conscientes - om saam met God te mag weet! - gebeur alleenlik

\footnotetext{
:38. Bv Barth. aangehaal bl. 800.

39. Sien veral bl. 810 e.v.

40. a.w. bl. 818 .

41. a.w., 821 .
} 
in die "Gleichzeitigkeit und Kongenialităt und indirekte Identifikation", wat na sy wese „das freie . . . das eigentlichste, das intimste Tun des Wortes Gottes selbst ist" ${ }^{\prime \prime}$ ).

Hoe kan ek God ken, werklik die Here, as ek in laaste instansie eiemagtig met myself en my sisteme voor Hom staan en waarom wend ek my nog tot die Skrif as dit vir my slegs 'n „episode" is en nie die geheimnis van Jesus Christus self nie?

Heel kort en ter sake moet ons die weg van Bultmann volg; veral waar dit deesdae - selfs binne Duitsland - gedink word dat daar ' $n$ tyd was dat Barth en Bultmann min of meer vanaf dieselfde posisie uitgegaan het, terwyl hulle van die grond uit diametraal teenoor mekaar staan.

Bultmann gaan „Geschichtlich" van die „Zugänglichkeit” van die Bybelse getuienis uit. Hierdie moontlike toegang tot die Bybelse getuienis is vir hom „Bedingt" volgens die reëls van die algemene hermeneutiek wat 'n erfenis is van Wilhelm Dilthey (,Die Entstehung der Hermeneutik”). Daarom is vir Bultmann „Verstehen" net moontlik waar daar 'n „Verwandschaft zwischen Autor und Ausleger" ${ }^{13}$ ) bestaan. Hierdie „Kongenialität" is vir Bultmann beperk tot die menslike moontlikhede! Presies soos die ou „religieuse apriori" keer nou die „Vorverständnis” by hom terug. NIE Gods Woord is die uitgangspunt nie, maar "die Wahrheit unserer Existenz". Karl Barth gaan uit van Gods antwoord en verneem ons vrae daaruit, Bultmann wil die menslike vraag aan die Kerugma stel. Die grondfout hierin sê Otto Weber in weinig woorde: „Unsere eigene Frage wird sich in ihrer Grundintention nie aus der Antwort Gottes treffen"t4). God sê nie aan ons wat ons in ons eie "bewussyn" verwag nie, maar wat ons hier in die mens Jesus Christus bereik: „eine unerwartete, fremde Kunde" ${ }^{45}$ ). Otto Weber wys Bultmann af op grond van teologiese beslissings wat Barth tevore reeds bereik het: „Kann man das menschliche Verstehen der biblischen Schriften aus allgemeinen Verstehenskategorien beschreiben, ohne schon im voraus zu wissen, dass ihm gegenüber diesem Zeugnis eine Entscheidungsbezogenheid zukommen wird, die sich nich aus allgemeinen Kategorien wird herleiten lassen?" ${ }^{* 6}$ ).

Terwyl Bultmann positief insien dat die „rein historisch arbeitende Schule" nie by die inhoud van die Bybel kan uitkom nie en dat die teologiese inhoud ook 'n teologiese uitleg vereis, trek hy die linies tussen God en mens, „Diesseits und Jenseits”,

\footnotetext{
4... a.w., 826 .

4. Glauben und Verstehen, II, 1952, 217 e.v.

44. Otto Weber Grundlagen der Dogmatik, I, 1955, bl. 345.

4.. a.w., bl. 346.

46. a.w., bl. 346.
} 
so radikaal dat die moontlikheid van Gods menswording ontken word ${ }^{17}$ ). Daar eindig dit nie: Bultmann loën nou dat die mens ooit die waarheid oor God kan uitspreek; God bly deus absconditus, en alles wat ons sê oor "Gods Openbaring" is net wat met die mens gebeur deur die ontmoeting, dit is veranderings ,des menschlichen Selbstverständnisses". Eenvoudig en finaal gestel: „Damit wird die Theologie zur Anthropologie, und die Christologie zur Soteriologie; Bultmann schneidet sich dadurch selbst die Möglichkeit einer biblischen Theologie $a b^{3+4}$ ).

Omdat hierdie "hermeneutisch uitgangspunt" die „voorafgaande levensverhouding tot de zaak" veronderstel ${ }^{19}$ ), daarom is daar by Bultmann, sover ek sien net 'n monoloog. Alles wat nie as "mythos" as mitologiese bekleedsel-geabstraheer kan word, sodat slegs 'n kern van "Selbstverständnis" oorbly nie, is net vir die Kerugma as boodskap onbruikbaar en word verwerp. Daar is geen inhoud nie! Wat Amos N. Wilder 'n bietjie later van Ernst Fuchs sou sê, is ten volle waar van Bultmann, waar dit alles begin: „My chief difficulty throughout, then, is that Fuchs refuses to define the content of faith . . . Fuchs carries this so far that revelation, as it were, reveals nothing! ${ }^{50}$ ).

Karl Barth het 'n nuwe horison gesien, uit die afgronde van loutere subjektivisme, die ontmoeting van die lewende God, wat soewerein vry is en my vrymaak vir sy Woord. Sedertdien het op hierdie hermeneutiese terrein nog niks nuuts weer sigbaar geword nie.

As Bultmann aanhoudend kla dat Barth en andere (selfs Käsemann, sy leerling) hom misverstaan ${ }^{51}$ ) dan merk Sevenster tereg aan dat dit nie gaan om 'n soort sintese hier nie, maar inderdaad 'n ,entweder oder". $\mathrm{Na}$ veel gesprekke en groot geduld, gesien die vurige, profetiese stem van weleer, het Barth self ook nou onomwonde uitgenooi tot 'n finale keuse: nie ,.jenseits von Barth und Bultmann" nie, ook nie Tillich of Bonhoeffer ingewerp nie, maar elke weg tot die einde bewandel. Sevenster het Bultmann se ,konsekwensies” heel eenvoudig deurskou. Duidelik is dat op die keper beskou Bultmann Paulus se hele teologie reduseer tot "Lehre vom Menschen" ${ }^{52}$ ) dat hy nie

4. J. D. Smart, Hermeneutische Probleme der Schriftauslegung, Heidelberg, 1965, bl. 265.

4.. Smart a.w., bl. 265.

19. Spelregels, een bundel essays over hermeneutische regels en hul toepassing in de theologie, Amsterdam, 1967. Hier: J. N. Sevenster, bl. $54 / 55$.

$\therefore$. A. N. Wilder, ..The Word as Address and Meaning", in „The New Hermeneutic". bl. 213.

:1. Glanben und Verstehen, IV, 1965, bl. 190.

5:- R. Bultmann, Theologie des Neuen Testaments, 1948, bl. 187 vv. 
daarvan terugdeins om Paulus te beskuldig van ' $n$ fatale ${ }^{\text {is) }}$ misstap nie, dat hy, aldus Sevenster eerder verhinder dat Paulus begryp word, dat 'n mens aan die „,bedoeling” van die tekste verbygaan, ,die eerder verduisteren dan verhelderen" ${ }^{5-4}$ ).

Nou is ons terug by die begin van hierdie paragraaf: waarom gaan dit eintlik as ons by die ken van God kom? Dit gaan om 'n potentia oboedientialis wat ons nie besit nie, om 'n afskeid aan enige vorm van habitas of securitas van ons eie. Wat is Openbaring as ons 'n adekwate instrument daarvoor het? Wat bly oor, as Bultmann op sy eie wyse in sy bekende boek oor „Eschatologie en Geskiedenis" met die opmerking eindig dat die eschatologie die geskiedenis verslind het (,Verschlungen"!)? As daar nie 'n ,tatsächliche Antwort" ${ }^{\text {5.3 })}$ van God gegee word nie, as daar nie ,geskiedenis" is, 'n konkrete en werklike "Gegenüber" nie, dan het ons ook geen ruimte en geen Woord nie!

Evangelies aangrypend is die verset uit die eie skool van Bultmann, wanneer dit weer gaan om die teenwoordigheid van die Kruis van Jesus Christus - „wirklich um Jesus und sein Kreuz"; natuurlik óók verset teen allerlei teologieë en tradisies (wat die pad tot Hom afsny!), want in die voortdurende afwisseling van die teologieë is dit duidelik dat „Gott sich nie von uns in die Tasche stecken lässt"sis) dat dit waarvoor ons kan lewe en sterwe, „Gottes Wahrheit”, ons ontmoet „am Kreuze Jesus . . . (waar) . . . „das erste Gebot aufgerichtet und erfüllt (wird)" "5i).

So dan staan in die vroeë twintigerjare diametraal teenoor mekaar Barth en Bultmann; Barth met die teks wat verstaan kan word alleenlik as subjek, vanuit sy eie subjektiewe inhoud; die Subjek is altyd groter as die interpreterende woord - en Bultmann met sy „Sachkritik", wat vanuit die menslike situasie nooit radikaal genoeg kan wees nie.

Ek herhaal dat die groot verskil tussen hierdie twee wyses van verstaan nié eers met Bultmann se „Entmythologisierungsprogram" sigbaar geword het nie, maar dis in die geboorte-ure van Barth en Bultmann se weë teenwoordig. (Hier moet nagelees word „Die Christliche Welt" en die „Theologische Literaturzeitung" van 1922! Erich Fascher gee in 'n "Grundriss" ook al die wesenlike diskussie - Januarie 1930.)

So vroeg as 1924 staan alreeds opgeteken in „Die Auferstehung der Toten”, bl. 4: „Die Wahrheit und die Würde des Zeugnisses von Christus liegen in dem, was in ihm dem Menschen

\footnotetext{
:3. Bultmann Kerygma und Mythos, I, 1960, bl. 44.

it. Sevenster, a.w., bl. 64/65.

s.s. K. Barth, K.D. I, 2. bl. 511.

s6. Ernst Käsemann. Die Gegenwart des Gekreuzigten, in (Christus unter Uns). 1967, bl. 8.

3i. a.w., bl. 9.
} 
begegnet von Gott! begegnet, nicht was er als Mensch dabei wird und was er daraus macht, nicht in dem logos oder der gnosis, mit der der Mensch es aufnimmt . . . Gott bleibt immer Subjekt in dem Verhältnis, das durch diese Zeugnis geschaffen wird."

So het Barth ons geleer van die begin af tot die einde: „Then let me say first of all that my thinking in any event remains at one point the same as ever. It is unchanged in this, that not so-called ,religion" is its object, its source, and its criterion, but rather, as far as it can be my intension, the Word of God"s9).

En Bultmann? Ook al in 1924: Insake God as subjekt: . . . „richtig! aber in unserem Reden, soweit wir es unternehmen müssen (also etwa im Geltendmachen des apo tou theou), ist Gott Objekt"s9).

So staan twee wêrelde teenoormekaar wat in ons dag die hele teologiese wêreld onoorbrugbaar verdeel het.

4.

\section{DIE HUIDIGE SITUASIE:}

Die huidige toestand in die evangeliese teologie word gekenmerk deur 'n uiteensetting tussen die leerlinge van Barth en Bultmann, met name soos die van Brunner, Gogarten, Tillich tussenin en in die afronding tree na vore Moltmann en Pannenberg. Terwyl ons nou toetree tot ons eie tyd, kan die omlyning baie sketsmatig wees, aangesien daar veel en goeie geskrifte daaromtrent bestaan en in enigeen daarvan die stippellyne maklik gevolg kan word"

Die verrassende van die teologie van ons tyd is dat die Grondvrae van die Ou Testamentiese hermeneutiek in die middelpunt staan. Hierop het Barth meer as tien jaar gelede die aandag gevestig: „To me it is significant that presentday Old Testament scholars, especially in regard to the old yet always

\footnotetext{
. K. Barth llow I changed my Mind. 1969, bl. 37.

59. R. Bultmann, Glauben und Verstehen, I, bl. 41.

:i". Onder die bestes is: Eberhard Hubner, Evangelische Theologie in unserer Zeit. Bremein, 1966. "New Frontiers in Theology" Dl. II, van Robinson and Cobb, recds aangehaal, vanaf bl. 39 c.v. is nuttig. Behalwe spesifieke werke, wat hier en daar vermeld sal word, verwys ek vir looflyne na Ilorion, Christian Theology, 1955; die verskillende werke van T. F. Torrance - vanaf sy "Theology in Reconstruction" - wat almal soek om sekere aspekte van dic teologie te deurvors: Emanuel Hirsch, se vyfdelige, "Gieschichte der neuern evangelischen Theologie”. wat egter meer met die "magte" in die geskiedenis worstel as met die teologie, Bertelsman. 1949. e.v. Neue Grenzen, Twee dele, uitgegee deur Klaus von Bismarck en Walter Dirks, Berlyn en Olten, 1966, en 1967. Ek verwys nog slegs na Arnokd Nash. Protestant Thought in the Twentieth Centurv. New York, 1951; Stenhen Neill, ed. Twentieth Century Christianity, London, 1962; B. G. M. Reardon, Religious Thought in the Nineteenth Century, C.U.P., 1966.
} 
new theme of ,faith and history', are on the whole on much better ground than the authoritative New Testament men, who to my amazement have armed themselves with swords and staves and once again undertaken the search for the 'historical Jesus' - a search in which I now as before prefer not to participate" ${ }^{\prime \prime 1}$ ).

'n Ry van uitnemende Ou Testamentici hoef hier maar net genoem te word: Gerhard von Rad, Hans-Joachim Kraus, Hans Walter Wolff, Walter Zimmerli. Hulle werk vind sy neerslag in die beroemde „Biblischer Kommentar Altes Testament”. As "Herausgeber" doen Rolf Rendtorff 'n grnot werk.

Dit gaan in hoofsaak om „die Wiederentdeckung der theologischen Bedeutung der Geschichte im Alten Testament" ${ }^{\prime 2}$ ). Heilsgeskiedenis word opnuut die sleutel o mdie teologiese struktuur van die Ou Testament te ontsidit. Die „Geschehen" soos deur die Ou Testament betuig, won u self ,zur leibhaften Anrede an den Menschen”'3). As daar ... die Israelitiese „Umwelt" mitologiese bestanddele was, is dir waaklik klaar "entmythologisiert". Daar is in Israel nie so iets as ,geskiedskrywing" "ohne Deutung" nie, en die "Deutungsprinzip is die verkondigde Woord van God $^{* 4}$ ). Zimmerli het dit mooi uitgedruk in die woorde: „das Wort Gottes, das ganz Geschehnis geworden, und das Geschehnis, das ganz und gar Wort Gottes ist."

In die uitleg van die Ou Testament tree opnuut na vore die „typologie" en ",analogıe”. En in die geheel is dié belangrikste ..Ergebnis" dat "Religion" in sy „Offenbarungschonmacht" onthul is, terwyl die „Otenbarungsverständnis", tevore deur Barth aangekondig, oor die nele linie veel dieper deurgewerk het.

In die stryd om die Nuwe Testament gaan dit soms in hoogste spanning om die „Existenzdialektik" van Bultmann cum suis. Hier moet aangemerk word dat teenoor die Ou Testament die Nuwe Testamentici van hierdie skool almal met mekaar verbind is deur hulle skema van Wet en Evangelie; terwyl ons in die Evangeliese teologie lankal geleer het dat die Wet, as Woord van God, net uit die Evangelie verstaan kan word!

Die grootste stryd het ontbrand rondom die vraag na die „historiese Jesus" ${ }^{\circ 5}$ ). Ernst Käsemann het in sy sterk referaat, wat wegbreek van Bultmann, sy ou leermeester, die weg aange-

\footnotetext{
¿1. Karl Barth, How I changed my Mind. 1969. bl. 69.

n?. Hübner, a.w.. bl. 176. Kursivering van My.

i:?. a.w., bl. 178.

ii. Sien veral Von Rad, Theologie des A.T., dl. II. bl. 351 v.: Zimmerli, Verheissung und Refullung, in E.v. Theol., $1952-53$. ur. 12.

n. Die groot versamelwerk weerspieël uitnemend wat in die debatte aangaan: ..Der historische Jesus und der Kerugmatische Christus", herausg. Ristow und Matthiae, Berlin, 1961.
} 
toon (voordrag in Marburg op 20.10.1953)66). Die ou vraag wat eers deur Martin Kähler aangesny is, word in 'n nuwe vorm weer opgewerp ${ }^{i i}$ ). Die eenvoudige verhoudinge soos dit verstaan is in ortodokse of liberale Jesusbeelde, is vir altyd verby. Die duidelike weg is nie van 'n ",sogenaamde historiese" Jesus na die Christus toe nie, maar helder is die prediking - wat altyd geld vir die teenwoordige tyd! - en tog berus op dié Jesus wat gelewe en gesterwe en opgestaan het. Vir die Gemeente was Hy Kurios, Here. Hoe gaan die weg tot Hom? Dit is die oer-vraag.

'n Koor van stemme is skielik daar! En die interessante is dat nie Barth se leerlinge nie, maar wel die van Bultmann telkens daarop wys dat hulle nie 'n goeie teologie kan bedryf sonder die historiese oergrond nie. So Bornkamm wat in sy "Jesus von Nazareth" hom daarop grond dat niemand in die "Altertum", ook nie die "grimmigsten Gegner des Christentums", daarvan droom om die historisiteit van Jesus te bestry nie. Ernst Fuchs gaan steeds verder op hierdie weg, want hy moet 'n getroue historiese kern hê om sy hele "spraakteologie" te bou. En al ken hy, soos trouens niemand uit die kringe, 'n „opgestane Jesus" in "geschichtliche" sin nie, dan nog kom hy tot die beslissing: "Jesus wagt es, Gottes Willen so geltend zu machen, als stünde er selber an Gottes Stelle!" Die samevatting van die ganse soektog word in die woorde van Hübner gedoen: „Ostern aber weckte und begründete den Glauben als den einzigen Zugang zur Wirklichkeit Gottes in Jesus";").

'n Leerling van Bultmann het die interessante beweging deurgemaak dat hy dwarsdeur die Bultmannse „historiese” en „Formgeschichtliche" Methode" heen by die wese van Barth se teologie gekom het: in die ",historiese Jesus" vind hy homself gestel ,,in der Struktur dialektischen Offenbarung Gottes." Dan kom hy op dieselfde fondamente as die vroeë Barth te staan en werk vandaar verder, dit is van Jesus Christus af in Wie „das Ereignis der Identität von Geschichte und Eschaton" deur sy opstanding verwerklik word. Hier vind die eschatologiese Ja van God tot die mens plaas. Hier breek Jüngel deur die Bultmannse subjektiwiteit soos niemand vandag nie, want eens en vir altyd gee hy die demonie prys om in "sprachliche" kategorieë hierdie eschatologiese gebeure vas te lê: „die Tätsächlichkeit der Offenbarung Gottes in der Geschichte, ist sprachlich nicht zum Ausdruck zu

::i. Das Problem der historischen Jesus, „Zeitschrift für Theologie und Kirche". Jhrg. 51. heft. 2, bl. 125 e.v.

:i- Martin Kähler, Der sogenannte historische Jesus und der geschichtliche, biblische Christus, verskyn in 1892, opnuut uitgegec in München, Chr. Kaiser Verlag. 1953.

6s. Hiibner, a.w., bl. 202. 
bringen" $\left.{ }^{69}\right)$. Ons kan net heenwys na hierdie gebeure; geen "supranaturele”, „mistieke” of selfs „dialektiese" kategorie kan formuleer wat hier gesê word nie, naamlik dat in die alleenlik (,nur”) historiese Jesus, Godself in die geskiedenis inkom. By Jüngel gaan 'n weg oop wat Godself in Sy Woord in die geskiedenis vashou teenoor alle natuurlike teologie aan die een kant, maar ook teenoor Bultmann, Fuchs, Ebeling, waar teologie niks meer is nie as ' $n$ faset van die Antropologie.

Ek volg hier nie verder die weg van Ebeling en Fuchs nie behalwe waar ek nog met teëstellings sal kom - aangesien daar werklik niks nuuts is nie. Dit bly oral dieselfde: die werklikheid van die mens bly die ,vorgeordnetes Kriterium" vir die inhoud van die verkondiging en die teologie! Daarom bly die verkondig ng leeg, koud, inhoudloos; en as daar van inhoud selfs sprake kon wees (Heinrich Ott!) ${ }^{-1}$ ) dan is dit steeds die „eksistentiale onto'ogie" van Heidegger.

Die verset wat daar gekom het en nog voortgaan teen die eksistensialisering en antropologisering van die ganse teologie is oorbekend uit die dogmatiese arbeid van Herman Diem, Helmut Gollwitzer, Hans-Joachim Iwand, Heinrich Vogel, Otto Weber en Ernst Wolf ${ }^{\mp 2}$ ).

By hulle almal is die Persoon van Jesus Christus die allesbepalende, in Wie, in reale, ,einmalige Geschichte”, die heenwysing is na die lewende God.

Moltmann en Pannenberg het ten slotte ons heeltemal teruggebring tot twee sake: die basiese uitgangspunte van die hermeneutiek én die spanning tussen geskiedenis en eschatologie ${ }^{73}$ ). Voorlopig wil ek as wesenlike en radikale beswaar aanmerk teen beide dat eerstens Moltmann die middelpunt, die tetelesthai (Joh. Ev.!), verplaas na 'n „Wirklichkeit die noch nicht ist"! In plaas van teologie is dit nog 'n keer 'n stuk ,geskiedfilosofie",

a.. a.w., bl. 204.

“". Vg]. hier Eherhard Jïnrel. Paulus und Jcsus, 1962; en dieper noz: Fin'tre sein ist im Werden. Tilbingen. 1965.

$\therefore$. Vgl. Heinrich Ott. Wirklichkeit und Glaube. Zürich. 1966. Fritz Buri tesame met Hans Jonas se werk kan beter onder die filosofie as teologie hehandel word. Vir ons huidige doel, kan hulle eenvoudig daargelaat word.

i2. F.k maak opmerksaam slegs on die deurslaggewende werke hier: HansInachim Iwand. Wider den Mischrauch des ..nro-me" als methodisches Prinzid in der Theologie. F. v. Theol.. 14. 1954. hl. 120 v.v.

Herman Diem. Dngmatik, Ihr Weg zwischen Historismus und Existentialismus. 1955 .

Helmut Goliwitzer, Die Existenz Gottes im Bekenninis des Glaubens, 1963.

73. Jurgen Moltmann. Theologie der Hoffnung. 1965. Wolfhart Pennenberg. (irundzüge der Christologie. 1964. Verder: Pannenberg, Grundfragen Systematischer Theologie, Göttingen, 1967. 
in plaas van die gevulde ruimte en tyd in Jesus Christus, weer eens 'n „Prinzip Hoffnung" - die filosofie naamlik van Ernst Bloch en weer is ons in werklikheid alleen!

Pannenberg se "geskiedfilosofie" wat teruggaan tot by Hegel, wil die dialektiek oorwin deur eenvoudig ,die ganze Geschichte (as) Offenbarung Gottes" te sien. Openbaring word vir hom inderdaad histories aanwysbaar; selfs die opstanding word voorwerp van historiese navorsing.

Dis belangrik om kennis te neem van die geweldige belangstelling in die geskrifte van Dietrich Bonhoeffer (1906-1945), wie se lewe en werk met ywer en toewyding bestudeer word. Dit bewys die sterke roepstem en nood om Christus te ken in die daad van die navolging. Ek dink egter nie dat hier enige nuwe bane geopen word vir die hermeneutiek nie.

Inderdaad is die groot probleme deur Schleiermacher gestel en wesenlik deur Barth beantwoord nog nie afgehandel nie dit toon die groot spanninge in die Evangeliese teologie vandag aan. Aan die een kant word al die gewig gelê op die moderne mens en ,das moderne Wissenschaftsverständnis", aan die ander kant gaan dit om die kernvraag: is dit die lewende God self wat ons in Jesus Christus ontmoet? Wat dieselfde vraag is as dit naamlik of hierdie geskiedenis, die getuienis is aangaande Hom, waarteenoor die teologie net kan staan as denke in diens van die ware ontmoeting tussen God en ons?

5.

\section{DIE KEN VAN GOD:}

Niemand ken God nie, ook nie één nie!

Daar is geen besondere hermeneutiek om God ooit te kan ken nie. Daar is geen metode om die Heilige Gees te besit nie; daar is geen hermeneutiek van die Heilige Gees nie. Die Heilige Gees kan ook in geen vorm van "Christelikheid” georganiseer word nie.

Die dwaalweë in die dogmatiek of hermeneutiek is altyd te wyte aan die feit dat die mens sekerheid soek, dat hy 'n sekerheidsmetode wil hê om - sy dit langs 'n ortodokse piëtistiese, rasionalistiese of historiese-kritiese metode - God te ken en te besit. Herman Diem verwys na Luther, wat met helder blik dwarsdeur hierdie menslike kortsigtigheid gesien het: „Den Grundfehler in all diesen Versuchen hat Luther vorausblickend angezeigt, wenn er sagt: Dazu mag ich nicht leiden Regel oder Masse, die Schrift auszulegen; dieweil das Wort Gottes, das alle Freiheit lehret, nicht soll noch muss gefangen sein" ${ }^{\prime 4}$ ).

74. Herman Diem, Theologie als kirchliche Wissenschaft, München, 1951, bl. 93. 
Daarom gaan dit: Kan ek God ken en God nie my gevangene, my stukkie privaatbesit - of dit nou al die van my Kerk of teologie is! - word nie. Daarom gaan dit of ek God wat God en Here is, kan ken!

Daar is geen kennis van God wat nie gebore word anders as deur die heilige donkerheid, die heilige ongeloof heen nie. Die geloofskennis bestaan nie anders as "ungeschützt" nie. Hoe sou ... geloof . . geloof wees en hierdie daad van ken egte kennis, indien dit 'n ander grond en bron en werklikheid sou hê as Hyself, as Wie $\mathrm{Hy}$ is!

Also, laat ons die weg nou in enkelvoudige stippellyn, inderdaad net stippels van stippels, volg, soos ek dit sien en wat aangegee word in die getuienis van Paulus wanneer hy sê: ,,sodat ck Hom kan ken en die krag van sy opstanding en die gemeenskap van sy lyde ..." Daar is die ontmoeting, die opstanding, die lyde. Die presiese omgekeerde weg van Sy aardse geskiedenis. In Sy geskiedenis gaan dit om lyding, opstanding en dan heerlikhcid; wanneer Hy ons ontmoet gaan dit eers om die herkenning, ontmoeting, heerlikheid - die woord wat ons kies om hierdie gebeurtenis te beskrywe, is nie die eintlik belangrike nie, maar die saak, dat God daar is in heerlikheid. Dan gaan dit om die inhoud van die ontmoeting, en dit is altyd die opstanding, die gekende Een is die Lewende, die Opgestane. Maar dan presies anders as in die lewe van die historiese Jesus - volg die lydingsgemeenskap: dit staan in die Credo gelyk aan ,die vergiffenis van die sondes." Aldrie hierdie momente is één! Maar die gebeure het 'n grond of eerste, 'n inhoud of tweede, en 'n hele lewe van navolging, lewe van vergiffenis, wat die bewys is van die kennis van God, en die derde dimensie is.

I. Dat ek Hom mag ken: dit gaan om die toegang tot Hom wat in feite beteken die toegang tot die getuienis aangaande Hom, waardeur Hy tot my kom. Hy het gekom en kom nou in hierdie geskiedenis. Dit is nie eenvoudig op die ry af die geskiedenis van Israel, dan die Nuwe Testamentiese gebeure, dan miskien die „ontmoetings" - of „Moment der Entscheidung” in die Kerkgeskiedenis nie. Dit is die toegang daartoe wat die geheimnis is: gebeur daar niks nie, dan is dit geslote en bly blote wêreldgeskiedenis en nie heilsgeskiedenis nie. Die werklikheid wat hier Woord is, wat spreek, getuig, is "die geskied": dit is die gebeure van die vryheid van God. Calvyn sou praat van "Soewereiniteit", Barth van „Vryheid" - wat in elke geval sê: God wat skenk, wat kom, wat laat gebeur. Wat Miskotte betuig, geld dwarsdeur: „Aber dem Wort begegnet man in der 
Zeit und nur in der Zeit, im vollen Masse nur in der Stunde. Es gilt sowohl von der Offenbarung wie vom Zeugnis von der Offenbarung, dass es ,geschicht' "is).

Wat geskied hier in hierdie geskiedenis: God kom in Jesus - dit is die eerste (die beweging van Hom tot die mens); dan die mens met Hom (die beweging van die mens tot Hom).

Die woord „God”, die geheel-enige éérste woord, behoef die hele Ou Testament en die hele Nuwe Testament om dit te vul! Die wonder van hierdie NAAM, hierdie ongehoorde gebeure waarin 'n Naam aan die mens geopen word. Hierdie Naam JHWH is Israel se eerste ontmoeting met Hom wat die groot EGO EIMI van die Nuwe Testament is: naamlik die groot Ek is! $\left.{ }^{6}\right)$.

Al die Name, vanaf die „Ek is", dwarsdeur tot die Ebed JHWH, die lydende Kneg: of dit nou ,die Heilige van Israel” is, of „die Vredevors", - alles sê net één ding God ontmoet die mens en die ontmoeting is nie leeg nie, maar dra 'n Naam. Die Woord wat Hy spreek (want sonder Woord vind geen ontmoeting ooit plaas nie!) is altyd Daad en word nooit fenomeen nie en hierdie "daad" is die grond en die rede vir die geloof wat slegs ant-woord is.

So staan dan die beslissings-, die ontmoetingskarakter van die kennis van God voorop: "u sluit my in van agter en van voor, en U lê u hand op my." Hierdie woord van Ps. 139 sê dit in één sin. Ook die eerste woorde:,Here, U deurgrond en ken my." Ons kennis van God begin met sy kennis van ons en in sy daad van ken, sluit Hy ons weg af: voor, agter, bó ons - dit wil sê elke weg, dáár is Hy, daar is Hy éérste.

Laat dit nog 'n maal gesê word: die geskiedenis van God met ons, die ganse geskiedenis is in sy grond, as fons et origens dit in eerste en laaste plek: ek word deur die lewende God gekonfronteer! Die daad van herkenning kom voor die daad van erkenning: die ontmoeting kom voordat ek Sy Naam kan uitspreek. Käsemann ${ }^{i i}$ ) stel dit hermeneuties: „Die Haupttugend des Historikers und der Anfang aller sinnvoller Hermeneutik ist für mich die Einübung des Hörens, die das geschichtlich Fremde zunächst einmal gelten lässt und nicht in der Vergewaltigung die Grundform des Engagements erblikt." Of soos Pannenberg in kort woorde sê: ". . . denn dieser Grund des Glaubens ist der Gott, der durch seine Verheissung auf die Zukunft verweist, die

$\therefore$ Miskotte, a.w., bl. 15.

ii. Sien die belangrike werk van Eduard Schweizer, EGO E.IMI. 1939.

$\because$ E. Käsemann, Exegetische Versuche und Besinnungen, II, 1964, bl. 107. 


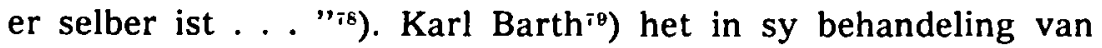
Feuerbach met groot skerpsinnigheid en 'n teologiese sedert hierdie grondwaarheid belig: dat die teologie sedert Feuerbach moet weet dat die woord "God" nie meer sonder verduideliking gesê kan word nie, dat die teologie nie mag handel asof hierdie woord vanselfsprekend is nie, dat 'n mens nie eenvoudig teologie ,uit die hoogte" kan bedryf nie.

Reg verstaan beteken dit tegelykertyd dat God in sy ontmoeting die denke ontsluit om sy gedagtes te dink; beteken dit dat die mens God mag en kan dink, as Hy Hom laat dink, laat ken, laat verstaan; beteken dit dat Hy Hom open vir die denke"

Dit is „der lebendigen Erkenntnis" waarvan Miskotte ${ }^{{ }_{1}}$ ) praat; van die besondere Teenwoordigheid in die tempel wat lei tot die algemene! Dit is in die woord van die Nuwe Testament: „In Hom was lewe, en die lewe was die lig." $D i t$ is ontsaglik belangrik: weer presies andersom as op die gewone menslike sensoriese of skematiese of rasionele weë van kennis waar dit van ,verligting” tot die „saak" of die werklikheid gaan. In die Evangelie is dit die lewe is lig! Eers Hy, eers sy Ontmoeting, eers die daad waarin God vir my God is, dan pas die verstaan daarvan. Opsy, neutraal, onsydig, van ver af: geen kennis nie. Barth het in die „Dogmatik im Grundriss"s") die ware ken van God vergelyk met sapientia eerder as scientia.

Dit is die waarheid wat lewensgemeenskap is; die Hebreeuse jd', (jáda'), wat in hierdie samehang in die Nuwe Testament (Mt. 1:25) sy weerklank vind - en veelvuldig in die Johanneise geskrifte voorkom! Josef het Maria nie „eginós” - ken, letterlik geken, dit is "gemeenskap" hê voor die geboorte van Jesus nie. Dit wil sê: ken, werklik ken in die Bybelse denke is hierdie totale ontmoeting van 'n hele persoon tot 'n hele persoon; en nog meer: die totale geskiedenis wat antwoord gee aan die totale geskiedenis. Die Boodskap van die Bybel is eenvoudig: God is teenwoordig!"3).

En nou is hierdie hele Emmánuelgeskiedenis die éen woord Jesus. Jesus wat Kurios is - nie omgekeerd nie, nie anders nie. Ook nie twee nie, maar Een: nie Jesus en Christus nie, maar „hierdie Jesus"! Daar is net Jesus wat Christus is.

\footnotetext{
$\therefore$ Wolfart Pannenberg, Grundfragen Sysiematischer Theologie, 1967, bl. 251.

:3. . Geschichte der protestantischen Theologie im 19 Jahrhundert", bl. 484.

4". Vgl. Karl Barth. K.D. I, 2, bl. 825.

$\because$. a w.. bl. 39.

\&2. ..Dogmatik im Grundriss", bl. 28, 29 e.v.

s.3. Vgl. ook Miskotte, a.w., bl. 13 .
} 
Ons is by die oergrond van die "Christelike kennis": hierdie Man is God! So sê die ou himne dit: ,die verborgendheid van die godsaligheid ... God is geopenbaar in die vlees." Dit is wat Jeremias, Käsemann en andere weer laat soek na ,die historiese Jesus" want in die Evangeliese getuienis spreek Hy in Gods plek, doen $\mathrm{Hy}$ in Gods plek.

Dit dan is die grond, die begin, die „waarsonder nie" van die kennis van God: Hy ontmoet ons.

Maar opdat dit nie formeel word nie, nie vir 'n oomblik nie, moet ons nou die tweede verneem.

II. Die Opstanding. Jesus leef! Dit is die hele Evangelie.

God ken is deur Hom ontmoet word en die inhoud daarvan is die opstanding. Dit is nie te veel gesê nie dat letterlik die hele inhoud van die hele Bybelse boodskap is die Opgestane Here! Van die begin tot die einde gee dit aan die Christelike geloof inhoud.

Karl Bornhäuser'') het op sy dag aangetoon dat vir oud-Israeı net iemand wat met volkome liggaamlikheid voor God staan versoening kan doen - dit kan geen ,skyn"-liggaam, of vae „siele-bestaan nie; daa:om moes Moses liggaamlik tot God gaan (sien bll. 259-263) - om versoenend by God in te tree. Vandaar dat alles daarop aankom dat Jesus as die liggaamlik opgestane Here verskyn, want Opstanding, nie voortbestaan nie, is die bewys daarvoor dat Sy dood versoen het!

Käsemann het reg: „Gott hat Jesus zum ewig gegenwärtigen Herrn gemacht, indem er ihn von den Toten auferweckte" ${ }^{\circ}$ ). Natuurlik het hy ook honderdmaal reg as hy in die ontwikkeling van sy boodskap sê: „Mit dem leeren Grab ist es absolut nicht getan, selbst wenn man es hundertfach bewiese"sc). Natuurlik, maar daarom gaan dit ook nie in die opstandingsboodskap nie, soos Johannes - op wie Bultmann hom graag beroep vir die volledige eschatologifisering van die ,geskiedenis" van Jesus! so glanshelder sê in sy opstandingsgeskiedenis (hf. 20:1-10), let veral op vs. 7: „die doek wat op sy hoof was, sien hy nie by die doeke lê nie, maar opgerol op een plek afsonderlik." Dit beteken: die doeke waarmee die ,gebalsemde" liggaam toegewoel is lê presies nog so! Die liggaam het opgestaan: het uit die uiterlike vorme, fenomene, vrygeword om lewend daar te wees!

Nogeens: wat word gesê, watter soort gebeure en geskiedenis is dit hier? Dit is die inhoud van Gods geskiedenis met ons! God lééf - Jesus lééf! Gods Naam kry sy ewige inhoud, in ons ken

\footnotetext{
". Das Wirken des Christus durch Taten und Wort Gütersloh. 1921, sien veral bl. 250-285.

$\therefore$ Käsemann. Die Gegenwart Christi, bl. 5.

sti. a.w., bl. 12/13.
} 
van God, in ons saamwees met Hom, in die opstanding. Hier is geen analogie, geen vergelykbare geskiedenis nie, geen kategorie waarmee ons dit kan vang of ,begryplik" maak nie; want wat sou "Vernunft" hier beteken, 'n blote abstraksie, want verstaan sonder hierdie geskiedenis maak van "verstand" 'n selfstandige grootheid sonder inhoud. Dat ons hier eers moet „entmythologiseer" of selfs sêkulariseer, beteken fakties dat nie die Woord ons verstand gee nie, maar die „ideëleer”, of wetenskapsleer of watter kenteorie of ideologie ookal. Wat sou beteken: Jesus, Jesus self is dood! Wat wil sê: die wêreld, hierdie aarde, hierdie liggaamlike bestaan en geskiedenis van menswees, is sonder hoop want dit is sonder God. Die God wat nie kan opstaan uit die dode nie, kan ook nie skep nie! Hy kan ideë fabriseer. Hy is nie die Here nie! By „hom” is geen kennis van God nie.

Oie inhoud van Gods kennis is die daad van die opstanding. Dit maak die Evangelie waar - nie "bewys" nie, nee: dit is die lewensinhoud van die Evangelie. Daarom is dit Paulus se Evangelie waarsonder hy niks weet en niks ken en niks verkondig nie. Dit is nie te veel gesê dat al Gods volheid hang aan die opstanding, want daarsonder is daar ook geen inkarnasie en ook geen betekenis hoegenaamd in die kruis nie!

Gods kennis bly nie 'n leë „,moment der Entscheidung” nie, bly nie 'n raaklyn sonder inhoud nie, maar is gevuld deur die opstanding wat beteken dat Hy my en my wêreld en my geskiedenis Syne gemaak het in tyd (juis in hierdie verlore tyd!) en in alle ewigheid. Dit is die gevulde geskiedenis, die gevulde ruimte waarin ek lewe.

Die liggaamlike triomf is ook in die Evangelies - in Lukas (sien hf. 24) waar alles daaraan geleë is dat Jesus liggaamlik teenwoordig is - en ook in Johannes, juis Johannes waar logos "vlees" word! - en waar die tas met die hande, sien met die oë, hoor met die ore ons tot martus getuies maak, en ons blydskap van communio volkome maak. Dis geen "fatale misstap" as Paulus aan hierdie oord staan en van hier die lig oor alles sien straal nie. Hier skyn die lig in die duisternis - of dit is nog nag, ons is nog alleen - ons ken God nie!

Opstanding is nie my idee, konsep, struktuur nie, maar die andere, die lewe van God!

III. Die finale het aangebreek, aangebreek in die omgekeerde orde wat ons verwag, in die omgekeerde weg waarop ook Kerk en teologie dikwels probeer lewe en getuig: die ken van God is die vergiffenis van die sonde! 
Dit is die bewys en waarmerk dat die lewende God self ons deur die opstanding van Jesus ontmoet het, dat ons die kruis opneem en Hom volg! NIE: ons ly in die wêreld, ons het swaar op aarde, dan die Opgestane, dan theologia gloriae. Nee, in die "wêreld" speel ons (selfs ook met pyn en lyding), maak ons filosofieë en rasionalisasies en moralismes, en wat nog, van alles, maar waar God ons ontmoet juis as die Lewende dáár is daar net een werklike ken van Hom: lewensgemeenskap met Jesus. Lewensgemeenskap met Hom nou en hier is die ,gemeenskap aan sy lyde", want dit is God se situasie in hierdie tyd en hierdie ruimte van ons. Sy heerlikheid is oor ons grense - daarom hemelvaart - maar sy teenwoordigheid is die Opgestane Here wat as Gekruisigde in die midde van sy gemeente is. Enige ander teologie, enige ander hermeneutiek gaan by Jesus verby en so by God verby.

Die lewe van die Gemeente oorwin die wêreld. Daarom het Bonhoeffer se lewe en dood so diep gegryp: die navolging van Jesus is die communio sanctorum. Tereg dat die wêreld siek word vir 'n ,teoretiese" Christendom, vir 'n Corpus Christianum, vir 'n Kerk wat nie op pad is, nie 'n bende dissipels van Jesus is nie.

So is die verskyning van Jesus na sy opstanding identies met vergiffenis van sonde. Daar is nie twee nie: die kennis van God as ontmoeting of as opstanding op sy eie nie, maar één: want Hom ken en vergiffenis ontvang is één en dieselfde saak. Ook hierin is ,ken" lewensgemeenskap. Ken is volg, is gehoorsaam: netsoos Hy wat gehoorsaam was tot die dood en dan verhoog word; so is ons weg terug tot Hom; ons wat van sy Kruis lewe, is ingesluit deur Sy Opstanding van agter en van voor.

Käsemann sê aan die punt nogeens iets vąn belang, naamlik „Dass der Jünger willig und fähig wird, Jesus irdisch das Kreuz nachzutragen, kennzeichnet ihn zugleich als Zeugen des auferstandenen Herrn, der ihm schon jetzt teilgibt an seiner königlichen Freiheit und dem Leben der zukünftigen Welt"sis). Also, dan tog "theologia crucis" - nein! - nie die "gloriae" of die "crucis" nie, maar die gekruisigde lewe wat leef van die opstanding. Dit is die lewe wat lig is.

$\mathrm{Ja}$, inderwaarheid, nie filosofieë, nie eers teologie:, ook nie „,kerkmismes" nie, maar „dissipelskap”, navolging, maak marturein, maak duidelik waar geloof en die ware ken van God uit die geloof is en nie nogeens blote ,bygeloof" nie.

si. a.w., bl. 17. 
Dis die Verhoogde Here alleen wat hierdie wonder verrig en wie dit minder as wonder überhaupt maak, ken nie die kennis van God nie - om ons vry en gewillig te maak om in hierdie wêreld geidentifiseer te wees met die Gekruisigde.

Daarom het Herman Diem ten diepste reg as hy die hermeneutiek 'n diens aan die verkondiging noem; dit is self marturein. En Eberhard Jüngel het honderdmaal reg met die tese: „Wenn der Text als Predigttext erscheint, hat die Hermeneutik im Raume der Theologie ihre Aufgabe getan" ${ }^{18}$ ).

So dan is en geskied die kennis van God: dit is die getuienis, die marturein,

ek is ontmoet,

deur Hom wat leef in ewigheid, Hy wat my vergewe.

Alleenlik ,vermöge der Auferstehung Jesu Christi von den Toten" (K.B.), is die Woord van God „uns zugänglich”, en hierdie toegang is die Kruis. Calvyn sê: "mortificatio et vivificatio". Dit is die weg. God ken, geskied nie sonder sterwe nie; sterwe aan myself.

Is ons ken van God dan tog 'n gryp na die Soewereiniteit van God? „So verhält es sich aber nicht, da der ewige Logos Gottes Fleisch angenommen hat, im Fleische auferstanden ist und im Fleisch ein Zeugnis seiner selbst begründet hat" ${ }^{\prime \prime 9}$ ).

Ons ken van God is resloos identies met Gods groot daad in Jesus Christus, God ken is opstandigsdaad, maar slegs deur die Kruis heen.

God ken, is met Jesus Christus gekruisig wees en die lewe wat ek leef Sy lewe te laat wees.

So leef die Gemeente in denke en lewe én volmaakte geheel: „En ons weet dat die Seun van God gekom het en ons verstand gegee het om die Waaragtige te ken; en ons is in die Waaragtige, in sy Seun, Jesus Christus. Hy is die waaragtige God en die ewige lewe."

ss. Eherhard Jüngel, Predigten, München, 1968, bl. 140.

s.. K. Barth, K.D. I, 2, bl. 804. 